\title{
Prevalence of streptocochemical hemolytic beta from group a in asympletic children
}

\begin{abstract}
Objective: This study aimed to determine the prevalence of Group A $\beta$-hemolytic streptococcus in oropharynx of asymptomatic children who attend a public school and also the sensitivity and resistance profile of these bacteria to antibiotics commonly tested

Methods: It was used sterile swabs to collect samples from the orpharynx of asymptomatic children for the accomplishment of microbiological culture. These children should not be using any antibiotic. For the differentiation of samples between others beta hemolytic species, bacitracin and L-Pyrrolidonyl- $\beta$-Naphthylamide tests were performed. All Group A $\beta$-hemolytic streptococcus samples were submitted to antibiogram test to establish the sensitivity and resistance profile.
\end{abstract}

Results: From the 229 samples analyzed the etiological agent of study was detected in $4.8 \%$. Antibiogram test was made and despite of the high sensitivity observed, there were cases of intermediate and/or total resistance to the antibiotics tested: betalactams, microclines and cephalosporin of the $3 \mathrm{rd}$ and 4 th generation. In addition, only one of the positive cases for the bacterium under study was sensitive to all antibiotics.

Conclusion: These results are relevant considering that bacteria belonging to Group A Beta-hemolytic Streptococcus are one of the microorganisms of major clinical interest, mainly when diagnosed in children. Thus, in order to reduce bacterial resistance to antibiotics it is important to use these drugs rationally.

Keywords: streptococcus, orpharynx, children
Volume 5 Issue I - 2017

\author{
Amanda Cristina de Oliveira Silva,' Daysiane \\ Roberta Souza da Silva,' Jucélia Ivonete dos \\ Santos,' Guilhermme Leandro de Sousa,' \\ Ruan Carlos Gomes da Silva,' Josefa Elaine \\ Silva Germinio, ${ }^{2}$ Sibele Ribeiro de Oliveira' \\ 'Asces-Unita University Center, Brazil
}

${ }^{2}$ Federal University of Pernambuco (UFPE), Brazil

Correspondence: Amanda Cristina de Oliveira Silva,AscesUnita University Center, Portugal Avenue, 584, University District, CEP: 55016-400, Caruaru - Pernambuco, Brazil,Tel +55 (8I) 993283597,Email amanda_cris_silva@hotmail.com

Received: June 0I, 2017 | Published: July 20, 2017
Abbreviations: EBHGA, group a streptococcus betahemolytic; RF, rheumatic fever; AP, acute pharyngitis; REC, research ethics committee

\section{Introduction}

Upper airway infections are one of the most common causes of medical appointment in clinical practice mainly faced by pediatric population. ${ }^{1}$ According to a study conducted by Morais et al. ${ }^{2}$ the incidence of respiratory tract infections due to $\beta$-hemolytic streptococcus can be more than 18times higher in children attending some day care center or environments where they are close to others sharing belongings. However, individuals of all ages are susceptible to propagation of this microorganism under conditions of overcrowding, because the interpersonal dissemination of these bacteria occurs through aerosolized microdroplets and/or by direct contact, mainly in environments where there are clusters of people. Among the diseases that affect the upper airways, acute pharyngitis (AP) is one of the most frequent in children. Although most of the AP is of viral origin, Group a Streptococcus Beta-hemolytic (EBHGA) presents as a significant bacterial etiological agent diagnosed in about $15-30 \%$ of acute pharyngitis. ${ }^{3}$ EBHGA or Streptococcus pyogenic is grampositive aerobic bacteria that causes a variety of infectious syndromes and is considered of great clinical interest due to its high pathogen city, usually involving or pharynx and skin, as a consequence these bacteria may cause several inflammatory diseases. One of the main laboratorial characteristics this pathogen presents to be identified and classified is the ability to shatter completely red blood cells in $5 \%$ sheep blood culture, causing a transparency in the culture medium, which is called Beta-hemolytic. ${ }^{5}$ Streptococcus pyogenic is important when compared to groups B, C and G, not only because it is the main etiological agent of streptococcal pharyngitis, ${ }^{6}$ but also because it causes suppurate complications such as, cervical adenitis, peritonsillar abscess, retropharyngeal or cervical abscess. ${ }^{7}$ In addition, EBHGA is related to other diseases such as streptococcal toxic shock syndrome, necrotizing fasciitis, scarlet fever and skin infections. ${ }^{8}$ According to Areas et al. ${ }^{9}$ its main complications are acute rheumatic fever, rheumatic heart disease and acute streptococcal disease, with a higher incidence especially in developing countries. Therefore, the early diagnosis of this condition, followed by adequate antimicrobial treatment, is extremely important not just for the prevention of rheumatic fever (RF) and other pathologies, but also for the reduction of EBHGA transmission among patients. ${ }^{3}$ Living in restricted settings, such as day care centers and schools, can greatly influence the dissemination of these bacteria, placing the health of children and adolescents at risk, ${ }^{10}$ considering that children and teenagers or pharynx is very sensitive to EBHGA infections, especially among 5 And 15years of age. ${ }^{11}$ Besides that, they can carry pathogenic microorganisms without presenting symptoms, characterizing the asymptomatic carriers. The epidemiological profile of this pathogen shows the relevance of it's diagnosed due to the existence of complications it may cause and their ease of transmission. ${ }^{2}$ Therefore, a precise etiological diagnosis contributes to avoid the abusive use of antibiotics and its consequences as the increase of bacterial resistance. ${ }^{12}$ This study aimed to determine the prevalence of Group A $\beta$-hemolytic streptococcus in or pharynx of asymptomatic children who attend a public school and also the sensitivity and resistance profile of these bacteria to main antibiotics tested. 


\section{Materials and methods}

It was a cross-sectional and descriptive study, which was performed between February and October, 2016 in a public school in the city of Caruaru-PE. The study was approved by the Research Ethics Committee (REC) of the Tabosa de Almeida University (Asces-Unita) under the opinion $\mathrm{n}^{\circ}$ 49273815.4.0000.5203. This study has begun after parents and/or Responsible for each child sign the Free and Informed Consent Form. The main inclusion criteria to participate of the research includes, asymptomatic children aged 5 to 15 years who were duly enrolled in the school chosen to carry out the study. In order to be classified as "asymptomatic", they could not present previous signs or symptoms of infection, for example: sore throat, fever, increased sensitivity of the cervical ganglia, hyperemia, edema, etc. Moreover, it is necessary do not use any kind of antibiotics trying to avoid changes in the examination or false negative results. The pharynx samples were collected in the morning, by using sterile swabs and tongue depressors. It was performed twists of $360^{\circ} \mathrm{C}$ on the right and left palatine tonsils. Then, these samples were transported into a Stuart medium in an isothermal container to the Laboratory of Microbiology at Taboos de Almeida University (Asces-Unita).

At the laboratory, the material was seeded by depletion in Petri dish containing Mueller Hinton agar medium (KASVI) plus 5\% sheep defibrinated blood. Then, the plates were incubated in a stove at 36$37^{\circ} \mathrm{C}$ during 24 hours in order to visualize possible beta hemolytic formed. All beta hemolytic colonies were isolated again in 5\% sheep blood agar to obtain pure colonies and after 24hours of incubation, these colonies were stained by the Gram technique. Samples that presented as Gram-positive cocci were firstly tested for the production of the enzyme catalase, to characterize microorganism as belonging to the genus Streptococcus. Subsequently, its differentiation between the other beta hemolytic species was performed through complementary tests as bacitracin and L-Pyrrolidonyl- $\beta$-Naphthylamide (PYR), confirming the bacterium EBHGA. EBHGA strains were evaluated for their susceptibility profile and resistance to antibiotics by in vitro antibiogram test. The technique performed was disc diffusion method as recommended by Kirby \& Bauer also, the antibiotics tested were selected according to the CLSI (Clinical and Laboratory Standards Institute) 2016. In order to present statistical data collect from this study, tables were made with the variables tested, the resistance and sensitivity profile were described using percentages. The tables of results were created and stored by using Excel 2010 (Microsoft Office $\left.{ }^{\circledR}\right)$.

\section{Results and discussion}

From 297 hildren whose parents and/or guardians signed the Free and Informed Consent Term, 157 were male and 140 were female. From this quantitative, 10children left the study and 58 do not applied to inclusion criteria proposed. At the end, 229children participate of this clinical research. The results obtained from the analyzed samples, as shown in Table 1, determined that $11(4.80 \%)$ of the children were colonized by EBHGA. Regarding antibiotic test, from 11samples analyzed, 10 showed intermediate or total resistance to at least one antibiotic tested and only one bacteria showed total sensitivity (Table 2 ). The antimicrobials which bacteria were resistant to the isolated EBHGA samples were: Penicillin and Cefepime (54.54\%), Ceftriaxone (45.45\%), Clindamycin and Ampicillin (27.27\%) and Vancomycin and Erythromycin \%). Although the prevalence of EBHGA was relatively low in our study $(4.80 \%)$, the values coincide with a study carried out by Maciel et al. ${ }^{6}$ in which from the 753samples analyzed in asymptomatic children, only 6 presented positivity for the same pathogen of this study. In Spain, a similar work verified a prevalence of $6 \%$ in asymptomatic schoolchildren. ${ }^{13}$ Another study carried out by Scalabrin et al. ${ }^{14}$ presented higher results compared with the above mentioned, which $15(25.90 \%)$ from the 58 participants had positive culture for EBHGA collected in pharyngotonsillitis. Following the recommendations of the CLSI 2016 it is noted that, one of the betalactam antibiotics tested, penicillin, remains one of the main drugs of choice for the treatment of infections caused by EBHGA, considered universally sensitive to penicillin's. ${ }^{7}$ For this reason, it is important to test penicillin through in vitro analysis by using the antibiogram, in order to obtain relevant data about the efficiency of this drug. Regarding resistance and sensitivity to antimicrobials, Scalabrin ${ }^{14}$ reports that all the samples tested showed a high sensitivity to penicillin. Other studies, such as those by Lopardo et al. ${ }^{15}$ also show their efficacy. This study, however, showed five resistant strains and one intermediate to penicillin. Similar information was found in a study made by Antunes et al. ${ }^{4}$ where penicillin no longer proved to be as efficient in invasive EBHGA infections.

Table I Isolation of EBHGA in asymptomatic children, according to age and positivity

\begin{tabular}{lllll} 
& Age & $\begin{array}{l}\text { Collections } \\
\text { held }\end{array}$ & Positive cases & Prevalence EBHGA \\
\cline { 2 - 5 } & 5 & $\mathbf{N}^{\mathbf{0}}$ & $\mathbf{N}^{\mathbf{0}}$ & \% \\
& 6 & 17 & 0 & - \\
7 & 30 & 1 & 0,44 \\
8 & 20 & 1 & 1,31 \\
9 & 39 & 1 & 0,44 \\
10 & 46 & 3 & 0,44 \\
11 & 22 & 2 & 1,31 \\
12 & 22 & 0 & 0,87 \\
& 13 & 16 & 0 & - \\
14 & 9 & 0 & - \\
15 & 2 & 0 & - \\
\hline
\end{tabular}

EBHGA, group a streptococcus beta-hemolytic 
Table 2 Sensitivity and resistance to tested antimicrobials

\begin{tabular}{|c|c|c|c|c|c|c|c|c|c|c|c|c|}
\hline Antibiotic & SIGLA & PC1 & PC2 & PC3 & PC4 & PC5 & PC6 & PC7 & PC8 & PC9 & PC10 & PC11 \\
\hline CLINDAMYCIN & CLI & $\mathrm{S}$ & I & $\mathrm{S}$ & S & $\mathrm{S}$ & $\mathrm{R}$ & I & $\mathrm{S}$ & $\mathrm{S}$ & $\mathrm{S}$ & $\mathrm{S}$ \\
\hline CEFTRIAXONE & $\mathrm{CRO}$ & $\mathrm{S}$ & I & $\mathrm{S}$ & S & I & I & $\mathrm{S}$ & $\mathrm{S}$ & $\mathrm{R}$ & $\mathrm{R}$ & $\mathrm{S}$ \\
\hline PENICILIN & PEN & $\mathrm{S}$ & $\mathrm{R}$ & $\mathrm{S}$ & S & $\mathrm{S}$ & $\mathrm{R}$ & I & $\mathrm{R}$ & $\mathrm{S}$ & $\mathrm{R}$ & $\mathrm{R}$ \\
\hline CEFEPIME & $\mathrm{COM}$ & I & I & $\mathrm{S}$ & S & I & $\mathrm{R}$ & $\mathrm{R}$ & $\mathrm{S}$ & $\mathrm{S}$ & $\mathrm{S}$ & $\mathrm{R}$ \\
\hline VANCOMYCIN & VAN & $\mathrm{S}$ & $\mathrm{R}$ & I & $\mathrm{S}$ & $\mathrm{S}$ & $\mathrm{S}$ & $\mathrm{S}$ & $\mathrm{S}$ & $\mathrm{S}$ & $\mathrm{S}$ & $\mathrm{S}$ \\
\hline AMPICILLIN & AMP & $\mathrm{S}$ & $\mathrm{S}$ & $\mathrm{S}$ & $\mathrm{S}$ & $\mathrm{S}$ & $\mathrm{S}$ & $\mathrm{R}$ & $\mathrm{R}$ & $\mathrm{S}$ & I & $\mathrm{S}$ \\
\hline ERYTHROMYCIN & ERY & $\mathrm{S}$ & $\mathrm{S}$ & $\mathrm{S}$ & $\mathrm{S}$ & I & $\mathrm{S}$ & $\mathrm{S}$ & $\mathrm{S}$ & $\mathrm{R}$ & $\mathrm{S}$ & $\mathrm{S}$ \\
\hline
\end{tabular}

PC, positive case; $\mathrm{S}$, sensitive; I, intermediate; $\mathrm{R}$, resistant.

Ferreira et al. ${ }^{16}$ demonstrated that of the 20 strains tested, 19samples were resistant to penicillin, but none showed resistance to $3^{\text {rd }}$ and $4^{\text {th }}$ generation cephalosporin's, as evidenced by Marot et al. ${ }^{17}$ where the tested cephalosporin's were $100 \%$ effectiveness. In the present study, from eleven positive cases, five presented intermediate or total resistance to Ceftriaxone and six to Cefepime. In the case of microcline-class antibiotics, the incidence of resistance in 120patients with EBHGA in Portugal $^{18}$ was $13.5 \%$, equivalent to 16 children. In this study, from 11 positive samples, 5 presented partial or total resistance to macro ides (erythromycin and clindamycin), corresponding to $45.45 \%$. In Brazil, this data resembles a study by Weber ${ }^{19}$ where significant resistance to erythromycin was found.

\section{Conclusion}

From these results, the prevalence of EBHGA in asymptomatic children and the pattern of resistance found are worrisome, since this pathogen is considered one of the main pathogen of clinical interest in or pharynx. In this way, attention to Group A Beta-hemolytic Streptococcus in childhood is of paramount importance, as well as the awareness of the rational use of antibiotics by children. Thus, adequate orientation regarding antimicrobial therapy it is important in order to contribute to the reduction of bacterial resistance.

\section{Acknowledgements}

To the participants and coordinators of the public school, for collaborating in the development of this research, and Asces-Unita, for the structural support.

\section{Conflict of interest}

The author declares no conflicts of interest.

\section{References}

1. Pereira LMP, Juman S, Bekele I, et al. Achado de bactérias selecionadas em crianças de Trinidad com doença amigdaliana crônica. Rev Bras Otorrinolaringol. 2008;74(6):903-911.

2. Morais VMS, Orsi AR, Maranhão FCA, et al. Prevalence of B-hemolytic Streptococcus in children with special health care needs. Braz $J$ Otorhinolaringol. 2012;78(5):110-115.

3. Fontes MJF, Bottrel FB, Fonseca MTM, et al. Early diagnosis of streptococcal pharyngotonsillitis: assessment by latex particle agglutination test. J Pediatr. 2007;83(5):465-470.
4. Antunes R, Diogo M, Carvalho A, et al. Síndrome do choque tóxico por streptococcus pyogenes. Acta Med Port. 2011;24(S3):617-620.

5. Lino LM. Factores de virulência em streptococcus pyogenes. Dissertação (Mestrado em Biologia Celular e Biotecnologia). Universidade de Lisboa; 2010. 34 p.

6. Maciel A, Aca IS, Lope ACS, et al. Portadores assintomáticos de infecções por Streptococcus pyogenes em duas escolas públicas na cidade do recife, pernambuco. Rev Bras Saúde matern Infant. 2003;3(2):175-180.

7. Balbani APS, Montovani CJ, Carvalho LR. Faringotonsilites em crianças: visão de uma amostra de pediatras e otorrinolaringologista. Revis Bras Otorrinolaringol. 2009;75(1):139-146.

8. Sousa TYLL, Carvalho TM, Silva SS, et al. Prevalência de Streptococcus pyogenes em crianças e adolescentes com 1 a 13 anos de idade, TeresinaPI, Brasil. RBAC. 2012;44(3-4):173-176.

9. Arêas PG, Schuab RBB, Neves FPG, et al. Antimicrobial susceptibility patterns, emm type distribution and genetic diversity of Streptococcus pyogenes recovered in Brazil. Mem Inst Oswaldo Cruz. 2014;109(7):935939.

10. Braoios A, Oliveira LR, LimA IB, et al. Portadores assintomáticos de Streptococcus mpyogenes e Staphylococcus aureus entre crianças atendidas em uma creche. Colloquium Vitae. 2009;1(1):25-29.

11. Silva SF, Soares RPF, Santos SL, et al. Análise Comparativa da Prevalência de Streptococcus pyogenes em Secreção de Orofaringe de Escolares da Zona Urbana e Rural do Estado de Pernambuco. NewsLabedição; 2005.73 p.

12. Cardoso DM, Sabino HM, Gilio AE, et al. Faringoamidalite estreptocócica: comparação entre diagnóstico clínico e microbiológico. Pediatria (São Paulo). 2009;31(2):94-99.

13. Gonzales-Lama Z, Gonzales JJ, Lupiola P, et al. Portadores de Streptococcos Beta-hemolíticos em los grupo A. BYEMC, em escolares de lãs palmas. Enferm Infec Microbiol Clinic. 2001;8:271-273.

14. Scalabrin R, Buss GD, Iamaguchi KC, et al. Isolamento de Streptococcus pyogenes em indivíduos com faringoamigdalite e teste de susceptibilidade a antimicrobianos. Rev Bras Otorrinolaringol. 2003;69(6):814-818.

15. Lopardo HA, Hernández C, Vidal P. Resistencia de Streptococcus pyogenes a los antibióticos. Experiencia de once años en un hospital pediátrico de Buenos Aires. Acta Bioquím Clín Latinoam. 2004;38(2):151-157.

16. Ferreira LLM, Carvalho ES, Berezin EM, et al. Colonização e resistência antimicrobiana de Streptococcus pneumoniae isolado em nasofaringe de crianças com rinofaringite aguda. Jornal de Pediatria. 2001;77(3). 
17. Maroto DP, Quezel NM, Rodrízguez IL, et al. Situación actual de las resistencias a antibióticos en infecciones amigdalares. Acta Otorrinolaringol Esp. 2006;57:171-175.

18. Castro T, Jacinto N, Mateus AM, et al. Resistance of Streptococcus pyogenes to macrolides and penicillin in a paediatric. Acta Pediátrica Portuguesa. 2013;44(6):1453-1457.
19. Weber FT. Verificação dos índices de resistência do Streptococcus Pneumoniae e caracterização genotípica das cepas resistentes a eritromicina. Dissertação de Mestrado em Microbiologia Agrícola e do Ambiente pela UFRGS. Porto Alegre-RS; 2008. 